\title{
Preliminary study on haemocyte response to white spot syndrome virus infection in black tiger shrimp Penaeus monodon
}

\author{
C. B. T. van de Braak $^{1, *}$, M. H. A. Botterblom ${ }^{1}$, E. A. Huisman ${ }^{1}$, J. H. W. M. Rombout ${ }^{2}$, \\ W. P. W. van der Knaap ${ }^{1}$
}

${ }^{1}$ Fish Culture and Fisheries Group, ${ }^{2}$ Cell Biology and Immunology Group, Wageningen Institute of Animal Science (WIAS), Wageningen University, PO Box 338, $6700 \mathrm{AH}$, Wageningen, The Netherlands

\begin{abstract}
White spot syndrome virus (WSSV) has been a major cause of shrimp mortality in aquaculture in the past decade. In contrast to extensive studies on the morphology and genome structure of the virus, little work has been done on the defence reaction of the host after WSSV infection. Therefore, we examined the haemocyte response to experimental WSSV infection in the black tiger shrimp Penaeus monodon. Haemolymph sampling and histology showed a significant decline in free, circulating haemocytes after WSSV infection. A combination of in situ hybridisation with a specific DNA probe for WSSV and immuno-histochemistry with a specific antibody against haemocyte granules in tissue sections indicated that haemocytes left the circulation and migrated to tissues where many virus-infected cells were present. However, no subsequent haemocyte response to the virus-infected cells was detected. The number of granular cells decreased in the haematopoietic tissue of infected shrimp. In addition, a fibrous-like immuno-reactive layer appears in the outer stromal matrix of tubule walls in the lymphoid organ of infected shrimp. The role of haemocytes in shrimp defence after viral infection is discussed.
\end{abstract}

KEY WORDS: White spot syndrome virus - Haemocyte · Defence $\cdot$ Penaeid shrimp

Resale or republication not permitted without written consent of the publisher

Aquaculture of penaeid crustaceans is an economically important activity in different parts of the world, but it is severely affected by endemic and epizootic infectious diseases. Since 1992, white spot syndrome virus (WSSV), with its extremely wide host range (Lo et al. 1996a, Rajendran et al. 1999), has caused major economic losses in world shrimp culture and it is currently the most important disease agent.

Besides clinical signs of infection including characteristic white spots in the cuticle (Chou et al. 1995, Wang et al. 1999), histopathological signs revealed by

`E-mail: office@alg.venv.wau.nl light and electron microscopy have also been extensively described for WSSV-infected animals (Chou et al. 1995, Wongteerasupaya et al. 1995, Lightner 1996, Durand et al. 1997, Wang et al. 1999). In addition to antisera for immuno-detection (Zhan et al. 1999, Van Hulten et al. 2001a), DNA hybridisation probes have been developed in several laboratories (Chang et al. 1996, Durand et al. 1996, Wongteerasupaya et al. 1996, Lo et al. 1997) to detect virus-infected cells. Molecular primers based on these probes have been developed for WSSV detection by polymerase chain reaction (PCR) (Chang et al. 1996, Lo et al. 1996b, Van Hulten 2000). These molecular techniques are highly specific and have a high degree of sensitivity. Recently, a competitive PCR assay has been developed for quantification of WSSV (Tang \& Lightner 2000). In addition, the major WSSV structural proteins have been characterised and the complete genome sequence has been determined (Tsai et al. 2000, Van Hulten et al. 2000, $2001 b, 2002)$. In contrast to extensive research on the virus itself, little work has been done on the host response, particularly that of haemocytes, which are generally responsible for host defence (Söderhäll \& Cerenius 1992).

To develop effective infection controls, more information about the mode of infection and interaction between the virus and its host is needed. Therefore, we examined the haemocyte response to severe experimental WSSV infection in shrimp by sampling haemolymph and by using a combination of in situ hybridisation and immuno-histochemistry with tissue sections. Viral-infected cells were detected using a WSSV-specific DNA probe, and haemocyte granules were stained with the monoclonal antibody (mAb) WSH 8 (Van de Braak et al. 2000). In non-activated haemocytes, this mAb reacted with the large granules in hyaline cells, but the immuno-staining rapidly 
increased when the cells were non-specifically activated, which might also be followed by degranulation (Van de Braak et al. 2002b). The present study shows for the first time, haemocyte reactions after severe WSSV infection, and provides new insights into common haemocyte responses.

Materials and methods. Shrimp and experimental infection: Penaeus monodon shrimp, originating from Thailand, were kept as described by Van de Braak et al. (2000). WSSV was isolated from infected P. monodon from Thailand and injected into healthy crayfish Procambarus clarkii to propagate the virus as described by Van Hulten et al. (2001a). Moribund crayfish were stored at $-20^{\circ} \mathrm{C}$ until use for oral infection of shrimp. A group of 12 shrimp (15 to $20 \mathrm{~g}$ ) was acclimatised in an experimental recirculation system for $2 \mathrm{~d}$ and starved for $1 \mathrm{~d}$. The crayfish abdomen was removed and the hepatopancreas, which does not become WSSV infected, was separated from the cephalothorax. The infected tissue was fed to 9 shrimp, while 3 control shrimp were fed similarly treated uninfected crayfish tissue. After 3 h, uneaten tissue was removed. In order to insure successful infection, 3 shrimp were sampled at $48 \mathrm{~h}$ and 3 at $72 \mathrm{~h}$ after the start of feeding. The remaining shrimp that received infected tissue died within $5 \mathrm{~d}$. The 3 uninfected shrimp were sampled at $48 \mathrm{~h}$ after the start of feeding.

Sampling and haemocyte counting: Haemolymph was sampled and total haemocyte counts were determined using a Bürker counting chamber as described by Van de Braak et al. (2002a). The haemocytes were washed and cell monolayers were prepared for staining with haematoxylin and eosin (H\&E). Immediately after haemolymph sampling, the shrimp were fixed for 24 to $48 \mathrm{~h}$ in Davidson's fixative (Bell \& Lightner 1988). Tissue of the whole shrimp was prepared for histology as described by Van de Braak et al. (2000). After deparaffination in xylene and rehydratation in an ethanol series, sections of the 9 shrimp were H\&E stained and observed at 100 to $1000 \times$ magnification. The number of free circulating haemocytes in sinuses was determined by counting the number of cells distributed in 10 different areas in the H\&E-stained sections of each shrimp at $400 \times$ magnification. We tested if the differences in total haemocyte count and number of circulating haemocytes in sinuses between the noninfected and the WSSV-infected groups were significantly different using a Student's $t$-test $(\mathrm{p}<0.05)$.

In situ hybridisation and immuno-histochemistry: H\&E-stained tissue sections were observed and found to be highly infected with WSSV after challenge, as determined by the presence of many enlarged nuclei containing basophilic inclusions. Tissue sections of the infected and control shrimp that contained haemato- poietic tissue and lymphoid organ tissue were selected for double labelling. The corresponding sections and sampled haemocytes on monolayers were used for a combination of in situ hybridisation and immuno-histochemistry. After deparaffination of tissue sections and washing, the sections and cells were incubated with Proteinase $\mathrm{K}$, fixed in $0.4 \%$ paraformaldehyde and washed again. A $6 \mathrm{kbp}$ WSSV BamHI genomic fragment was digoxigenin (DIG)-labelled using a DIGDNA labelling mix (Roche) and added to the hybridisation buffer (Lightner 1996). After overnight hybridisation in this buffer, the tissue sections and monolayers were washed again and blocked. DNA hybridisation was detected using alkaline phosphatase conjugated anti-DIG, which was visualised with a standard solution of BCIP (5-bromo-4-chloro-3-indolyl phosphate) in conjunction with NBT (nitroblue tetrazolium) to yield a dark blue colour.

Immediately afterwards, an immuno-peroxidase reaction, with the mAb WSH 8 (1:100) was carried out as described by Van de Braak et al. (2000) and this resulted in a brown staining. The sections and cells were counter-stained with methylene green and examined at 100 to $1000 \times$ magnification. Micrographs were made using an Olympus DP50 Microscope Digital camera. Standard controls such as omission of the probe or replacement of WSH 8 by WCI 12 (a mAb against carp immunoglobulin) were carried out and were negative. In addition, in situ hybridisation and immuno-histochemistry were carried out separately and these showed the same reactions as in the combined staining. The small rod-shaped structures near the WSSV-infected cells that gave a blue colour similar to that for positive hybridisation with the DNA probe were artefacts of precipitated NBT.

The percentage WSH 8-positive haemocytes was determined in duplicate by counting 100 cells ind.$^{-1}$ at $400 \times$ magnification. It was tested if these differences between the non-infected and the WSSV-infected groups were significantly different by using a Student's $t$-test $(\mathrm{p}<0.05)$.

Results. Compared to uninfected shrimp, the amount of haemolymph that could be sampled from the infected shrimp was consistently reduced by more than $40 \%$. The total haemocyte counts and the number of free, circulating haemocytes in the H\&E-stained tissue sections were both significantly reduced after WSSV infection. However, no differences were observed between 48 and $72 \mathrm{~h}$ after start of feeding of the infected material (Table 1). The H\&E-stained haemocytes in monolayers and in circulation in the tissue sections never showed enlarged nuclei. After the combination of in situ hybridisation and immuno-staining of the haemocyte monolayers, the cells were negative for WSSV for both infected and uninfected shrimp and 
Table 1. Total haemocyte counts (THC) with standard deviation, mean number of haemocytes counted circulating in fields in tissue sections (No. circ. cells) and \% WSH 8-positive $\left(^{+}\right)$haemocytes in monolayers with standard error of noninfected (control $48 \mathrm{~h}$ ) and severely WSSV-infected (WSSV 48 $\mathrm{h}$ and WSSV $72 \mathrm{~h}$ ) shrimp. Standard deviation and standard errors sharing different superscripts differ significantly from each other $(p<0.05)$

\begin{tabular}{|lccc|}
\hline Shrimp & THC & No. circ. cells & \%WSH 8 \\
\hline Control 48 h & $31.8( \pm 12.0)^{\mathrm{a}}$ & $57.8( \pm 6.9)^{\mathrm{a}}$ & $5.6( \pm 2.9)^{\mathrm{a}}$ \\
WSSV 48 h & $13.3( \pm 4.3)^{\mathrm{b}}$ & $13.0( \pm 5.5)^{\mathrm{b}}$ & $3.5( \pm 2.5)^{\mathrm{a}}$ \\
WSSV 72 h & $10.4( \pm 1.0)^{\mathrm{b}}$ & $15.4( \pm 1.6)^{\mathrm{b}}$ & $2.6( \pm 1.9)^{\mathrm{a}}$ \\
\hline
\end{tabular}

there was no significant difference in WSH 8 reactivity between the infected and uninfected shrimp (Table 1).

The tissue sections of the 3 uninfected shrimp were negative for WSSV and showed a small subpopulation of WSH 8-positive haemocytes distributed in different organs (e.g. main sinuses, heart, connective tissue, and walls of the lymphoid organ tubules). In tissue sections of shrimp that were highly infected with WSSV, virusinfected cells were found in most organs, but not in the hepatopancreatic tubules, hepatopancreatic epithelium and midgut epithelium. The number of haemocytes that reacted with WSH 8 and the intensity of the WSH 8 staining in the haemolymph plasma increased after viral infection.

Many WSH 8-positive haemocytes were observed in tissues where large numbers of WSSV-infected cells were present, but they were absent in the same tissue in uninfected shrimp (e.g. in the epithelium of the stomach in Fig. 1a,b). The majority of cells in the haematopoietic tissue in uninfected shrimp were WSH 8 positive, but this number was greatly reduced in infected shrimp (Fig. 1c,d). Furthermore, the remaining cells in the haematopoietic tissue in infected shrimp were consistently enlarged, compared to those cells in uninfected shrimp.

In the lymphoid organ of uninfected shrimp, the number of WSH 8-positive haemocytes was low and they were generally located in the lumen of the lymphoid organ tubules (Fig. 1e). By contrast, WSH 8positive cells, together with many released granules, were present in high numbers in the lymphoid organ of WSSV-infected shrimp. These cells and granules were predominantly located in the outer portion of the tubule stromal matrix (Fig. 1f). At high magnification of lymphoid organ tubules of infected shrimp, granule staining changed into staining of extracellular fibrous material (Fig. 2). Lymphoid organ spheroids present remained WSH 8 negative in both infected and uninfected shrimp, and only sporadically showed virusinfected cells by in situ hybridisation (not shown). Some of the WSH 8-positive haemocytes that infil- trated tissues were also WSSV positive by in situ hybridisation (Fig. 3).

Discussion. Strong labelling of many nuclei in WSSV-challenged shrimp by in situ hybridisation with a WSSV-specific DNA probe confirmed that shrimp from both challenged groups were heavily infected with WSSV. Combined staining with WSH 8 confirmed viral replication in nuclei of non-circulating haemocytes, but circulating haemocytes positive for WSSV by in situ hybridisation were never observed. Both circulating and settled haemocytes have been suggested to be infected by WSSV in previous studies (Durand et al. 1996, 1997, Wang et al. 1999). In those studies, the WSSV-infected cells were designated as haemocytes based on cell morphology and location, and we observed that they were often morphologically altered. Thus, they may have included only non-circulating haemocytes. On the other hand, positive WSSV in situ hybridisation results with haemolymph smears of crabs and shrimp have been reported (Kanchanaphum et al. 1998). By contrast, our tissue sections clearly showed that free, circulating haemocytes never gave positive in situ hybridisation results for WSSV infection. We cannot explain the discrepancy in these results. It is possible that the difference was caused by poor attachment of infected cells on the glass slides (Wang et al. 2000) or by our method of processing the smears. It is also possible that the virus may penetrate settled cells more easily or that virus-infected haemocytes become activated and rapidly settle.

We found a strong decline in free, circulating haemocytes in WSSV-infected shrimp and this has also been reported by others following WSSV infection (Hennig et al. 1998, Kim et al. 1999). By contrast, this effect was not observed in WSSV-infected crayfish (Jiravanichpaisal et al. 2001). A decrease in total haemocyte count has often been described in crustaceans as a reaction after fungal and bacterial infection or after injection of foreign materials (Smith \& Söderhäll 1983, Persson et al. 1987, Lorenzon et al. 1999). A decline in circulating haemocytes after WSSV infection could result either from a haemocyte response or from infection, since haemocytes constitute a WSSV target. Distinguishing between these 2 alternatives is an important issue in terms of host viral interactions.

Although the number of haemocytes that could be sampled from the infected shrimp was small, those observed showed a lower WSH 8 reactivity than haemocytes from uninfected shrimp. Conversely, haemocytes in tissue sections increased in WSH 8 reactivity after virus infection. Whether the haemocytes first increase in WSH 8 reactivity and then settle, or the other way around, could not be deduced from the present study. Increased WSH 8 reactivity in the granular haemocytes has been related to haemocyte activation in vitro in a 
rich cell-culture medium (Van de Braak et al. 2000) and in vivo after bacterial injection (Van de Braak et al. 2002b). Therefore, our observations here showing increased WSH 8 activity in tissue sections suggests that haemocytes also become activated after viral infection. However, we saw no haemocyte reactions, like phagocytosis, aggregation or melanisation as commonly observed after non-viral infections.

Non-specific antiviral activities have been demonstrated in tissue extracts of a number of crustaceans (Pan et al. 2000), but haemocyte reactions have not been reported in chronic or acute viral infections in shrimp (Lightner 1996). The shrimp response to viral pathogens has been reviewed by Flegel (2001), who stated that haemocyte aggregation at sites of viral presence was not typical, even in the presence of considerable tissue damage. However, in addition to establishing that haemocytes are activated by WSSV infection, we have shown by WSH 8 reaction that granular haemocytes are present in higher numbers at tissue sites with many WSSV-infected cells. In our opinion, the results suggest that haemocytes leave the circulation and migrate to tissues where many virusinfected cells are present. Such haemocyte aggregation at the site of viral infection has never been previously reported in shrimp. Although the accumulation was not as massive as that usually associated with bacterial infections, it was certainly highly significant and justifies further study. Whether the haemocytes are attracted to WSSV-infected tissue specifically to remove virus-infected cells or non-specifically to remove degrading cells is not known and needs further investigation. This knowledge is extremely important when investigating the host response to viral infection.
The accumulation of granular haemocytes at sites of viral infection was accompanied by a decline in the number of granular cells in the haematopoietic tissue. This suggested that they had migrated from the haematopoietic tissue to infection sites. In addition, the remaining cells in the haematopoietic tissue of viral infected shrimp displayed a blast-like appearance, characterised by an increase in volume of nucleus and cytoplasm and a low intensity of WSH 8 reaction. These findings suggest that haemocytes stored in the haematopoietic tissue were released in reaction to the viral infection and that the activity of the remaining cells increased. Similar results have been described in haematopoietic tissue of shrimp repeatedly sampled for haemolymph and in lipopolysaccharide (LPS)injected shrimp (Van de Braak et al. 2002a).

The cells in the tubules of the lymphoid organ showed WSSV infection after challenge. Many viruses (Bonami et al. 1992, Hasson et al. 1999a,b, Anggraeni \& Owens 2000), but also bacteria (Van de Braak et al. 2002b), have been detected in the shrimp lymphoid organ. In non-infected shrimp, WSH 8 labelling showed clear granule staining in haemocytes in the central lumen of the lymphoid organ tubules. This WSH 8 staining changed to dispersed staining of the outer stromal matrix of the lymphoid organ tubules after WSSV infection. This has also been observed after injection of Vibrio bacteria by Van de Braak et al. (2002b), but to a much lesser extent. In that study, the phenomenon was attributed to degranulation of haemocytes in response to bacterial injection. The present results indicate that such a haemocyte response also occurs after viral infection. This degranulation might amplify the haemolymph filtering capacity of the lymphoid organ. The fact that the lymphoid organ

Figs. 1 to 3. Penaeus monodon. Light micrographs of histological sections of shrimp that were fixed $48 \mathrm{~h}$ after feeding of uninfected or white spot syndrome virus (WSSV)-infected crayfish tissue. Haemocyte granules were immuno-stained with the monoclonal antibody WSH 8 (goat antimouse-horseradish peroxidase, brown) and infected cells were labelled by in situ hybridisation, using the digoxigenin (DIG)-labelled DNA probe for WSSV (dark blue). WSSV-infected cells and WSH 8 reactive haemocytes are not observed in the epithelium of the stomach in non-infected shrimp (a), while many virus-infected cells and WSH 8-positive haemocytes are observed in the stomach epithelium in heavily infected individuals (b). WSH 8-positive haemocytes are densely packed in the haematopoietic tissue of non-infected shrimp (c). In the haematopoietic tissue of WSSV-infected shrimp, virus-infected cells are present, the cell density (as observed by a reduced number of nuclei), the number of WSH 8-positive cells and the staining intensity decreased (d). Note the differences in sizes of haematopoietic tissue nuclei between the uninfected and infected shrimp. WSH 8-positive haemocytes are abundant in the central haemal lumen of the lymphoid organ (LO) in non-infected shrimp (e), while many WSSV-infected cells are present in the LO tubule stromal matrix next to an outlying WSH 8 reaction in heavily infected shrimp (f). Counter-stained with methylene green. Scale bars $=20 \mu \mathrm{m}$. Fig. 2 . Light micrograph of combined in situ hybridisation and immuno-staining of haemocytes of a LO tubule of shrimp $48 \mathrm{~h}$ after the start of oral administration of WSSV. Haemocyte granules are stained with the monoclonal antibody WSH 8 (GAM-HRP; brown) and WSSV-infected cells are stained by in situ hybridisation (dark blue). Haemocyte granules are mainly present in haemocytes in the sinuses, while the outer tubule matrix shows dispersed WSH 8 labelling. Arrowheads point to WSH 8-positive haemocyte granules. Counterstained with methylene green. Scale bar $=10 \mu \mathrm{m}$. Fig. 3. Light micrograph of in situ hybridisation combined with immunostained haemocytes in the connective tissue of the hindgut, $48 \mathrm{~h}$ after start of oral WSSV infection. Haemocyte granules are stained with the monoclonal antibody WSH 8 (GAM-HRP; brown) and WSSV-infected cells are stained by in situ hybridisation (dark blue). The dark blue colour of the WSH 8-positive cell indicates that viral replication occurs in the haemocyte nuclei. Arrowheads point to haemocytes with dual staining for WSSV and WSH 8; the cell on the right is in a more advanced infection state. Counter-stained with methylene green. Scale bar $=10 \mu \mathrm{m}$. CT: connective tissue; E: epithelium; Hc: haemocyte; Lum: LO tubule lumen; Sin: haemolymph sinus; S Lum: stomach lumen; W: LO tubule wall. 

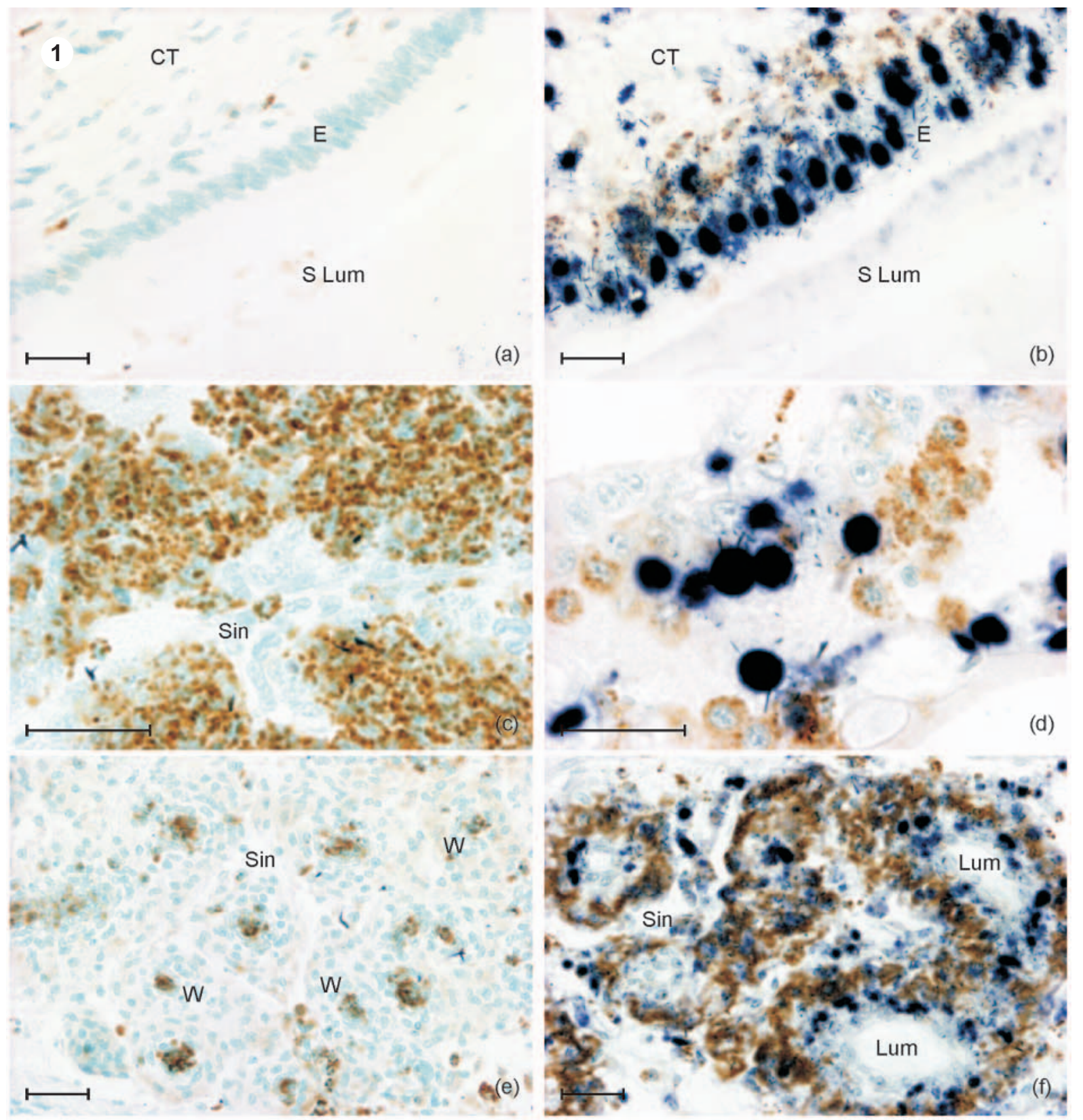

(a)

(b)
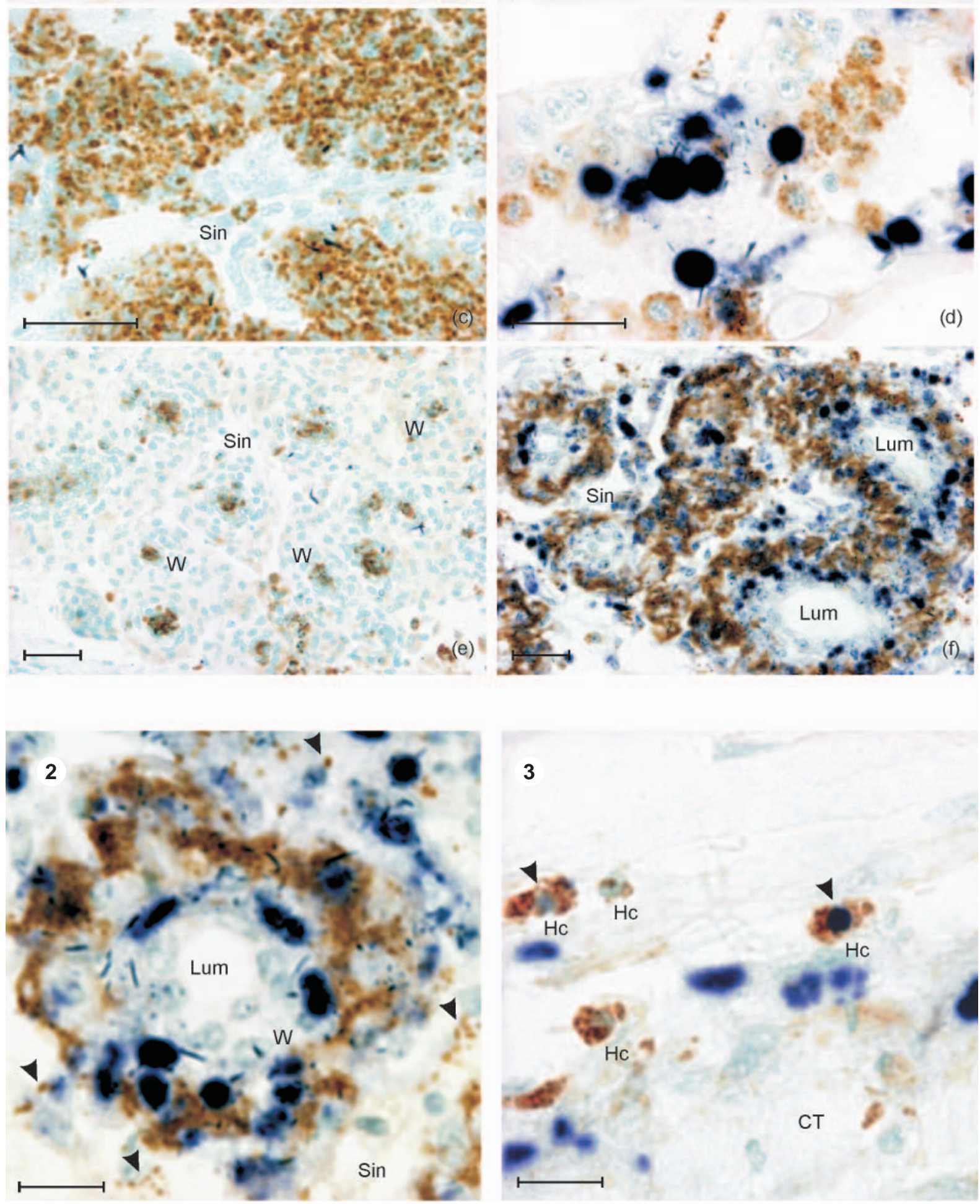
spheroids became only sporadically infected in the present study might be explained by the limited time of observation. Spheroid development has been described in Taura syndrome virus infections (Hasson et al. 1999a,b) and is often associated with other viral infections (Anggraeni \& Owens 2000).

In conclusion, heavy WSSV infection resulted in haemocyte activation and migration to infected tissues. However, in contrast to bacterial infection, massive haemocytic aggregation and melanisation were not observed. Our results showed consistent differences in haemocyte numbers and activity for haematopoietic tissue and lymphoid organ tissue between WSSVinfected and uninfected shrimp. Similar less extensive haemocyte reactions in these organs have also been found after non-viral stimuli. Therefore, the haemocyte reactions described here are probably general defence responses rather than specific antiviral responses. Further research should include the identification of the molecules recognised by WSH 8 . For a better understanding of the shrimp response to viral infection, molecular studies on viral pathogens, haemocytes, and the haemocyte defence system should be integrated and include the early events following viral infection.

Acknowledgements. This research was supported by Intervet International B.V., Boxmeer, The Netherlands. The authors wish to thank Dr. Eric Rijke (Intervet International), Prof. Willem B. van Muiswinkel (Cell Biology and Immunology Group) and Prof. Just M. Vlak (Virology Group) for critically reading the manuscript. Thanks also to Dr. Mariëlle C. W. van Hulten for critically reading the manuscript and supplying of labelled WSSV DNA and to Robert Kock for his contribution to this study as part of his Masters degree research project in Fish Culture.

\section{LITERATURE CITED}

Anggraeni MS, Owens L (2000) The haemocytic origin of lymphoid organ spheroid cells in the penaeid prawn Penaeus monodon. Dis Aquat Org 40:85-92

Bell TA, Lightner DV (1988) A handbook of normal penaeid shrimp histology. World Aquaculture Society, Baton Rouge, LA

Bonami JR, Lightner DV, Redman RM, Poulos BT (1992) Partial characterization of togavirus (LOVV) associated with histopathological changes of the lymphoid organ of penaeid shrimps. Dis Aquat Org 14:145-152

Chang PS, Lo CF, Wang YC, Kou GH (1996) Identification of white spot syndrome associated baculovirus (WSBV) target organs in the shrimp Penaeus monodon by in situ hybridisation. Dis Aquat Org 27:131-139

Chou HY, Huang CY, Wang CH, Chiang HC, Lo CF (1995) Pathologenicity of a baculovirus infection causing white spot syndrome in cultured penaeid shrimp in Taiwan. Dis Aquat Org 23:165-173

Durand S, Lightner DV, Nunan LM, Redman RM, Mari J, Bonami JR (1996) Application of gene probes as diagnostic tools for white spot baculovirus (WSBV) of penaeid shrimp. Dis Aquat Org 27:59-66
Durand S, Lightner DV, Redman RM, Mari J, Bonami JR (1997) Ultrastructure and morphogenesis of white spot syndrome baculovirus (WSSV). Dis Aquat Org 29:205-211

Flegel TW (2001) The shrimp response to viral pathogens. In: Browdy CL, Darryl EJ (eds) The new wave. Proceedings of the special session on sustainable shrimp culture, aquaculture 2001. World Aquaculture Society, Baton Rouge, LA, p 190-214

Hasson KW, Lightner DV, Mohney LL, Redman RM, Poulos BT, White BM (1999a) Taura syndrome virus (TSV) lesion development and the disease cycle in the pacific white shrimp Penaeus vannamei. Dis Aquat Org 36: 81-93

Hasson KW, Lightner DV, Mohney LL, Redman RM, White BM (1999b) Role of lymphoid organ spheroids in chronic Taura syndrome virus (TSV) infections in Penaeus vannamei. Dis Aquat Org 38: 93-105

Hennig O, Itami T, Maeda M, Kondo M, Natsukari Y, Takahashi Y (1998) Analyses of hemolymph immunoparameters in kuruma shrimp infected with penaeid rodshaped DNA virus. Fish Pathol 33:389-393

Jiravanichpaisal P, Bangyeekhun E, Söderhäll K, Söderhäll I (2001) Experimental infection of white spot syndrome virus in freshwater crayfish Pacifastacus leniusculus. Dis Aquat Org 47:151-157

Kanchanaphum P, Wongteerasupaya C, Sitidilokratana N, Boonsaeng V, Panyim S, Tassanakajon A, Withyachumnarnkul B, Flegel TW (1998) Experimental transmission of white spot syndrome virus (WSSV) from crabs to shrimp Penaeus monodon. Dis Aquat Org 34:1-7

Kim YJ, Choi WC, Kom HR, Jung SJ, Oh MJ (1999) Changes in Penaeus chinensis haemocytes during white spot baculovirus (WSBV) infections. Bull Eur Assoc Fish Pathol 19: 213-215

Lightner DV (1996) A handbook of pathology and diagnostic procedures for diseases of penaeid shrimp. World Aquaculture Society, Baton Rouge, LA

Lo CF, Ho CH, Peng SE, Chen CH and 7 others (1996a) White spot syndrome baculovirus (WSBV) detected in cultured and captured shrimp, crabs and other arthropods. Dis Aquat Org 27:215-225

Lo CF, Leu JH, Ho CH, Chen CH and 8 others (1996b) Detection of baculovirus associated with white spot syndrome (WSBV) in penaeid shrimps using polymerase chain reaction. Dis Aquat Org 25:133-141

Lo CF, Ho CH, Chen CH, Liu KF and 9 others (1997) Detection and tissue tropism of white spot syndrome baculovirus (WSBV) in captured brooders of Penaeus monodon with special emphasis on reproductive organs. Dis Aquat Org 30:53-72

Lorenzon S, De Guarrini S, Smith VJ, Ferrero EA (1999) Effects of LPS injection on circulating haemocytes in crustaceans in vivo. Fish Shellfish Immunol 9:31-50

Pan J, Kurosky A, Xu B, Chopra AK, Coppenhaver DH, Singh IP, Baron S (2000) Broad antiviral activity in tissues of crustaceans. Antivir Res 48:39-47

Persson M, Cerenius L, Söderhäll K (1987) The influence of haemocyte number on the disease resistance of the freshwater crayfish Pacifastacus leniusculus Dana, to the parasitic fungus Aphanomyces astaci. J Fish Dis 10: 471-477

Rajendran K, Vijayan KK, Santiago TC, Krol RM (1999) Experimental host range and histopathology of white spot syndrome virus (WSSV) infection in shrimp, prawns, crabs and lobsters from India. J Fish Dis 22:183-191

Smith VJ, Söderhäll K (1983) $\beta$-1, 3-glucan activation of crustacean hemocytes in vitro and in vivo. Biol Bull 164: 299-314

Söderhäll K, Cerenius L (1992) Crustacean immunity. Annu Rev Fish Dis 2:3-23 
Tang KFJ, Lightner DV (2000) Quantification of white spot syndrome virus DNA through a competitive polymerase chain reaction. Aquaculture 189:11-21

Tsai MF, Lo CF, Van Hulten MCW, Tzeng HF and 6 others (2000) Transcriptional analysis of the ribonucleotide reductase genes of shrimp white spot syndrome virus. Virology 277:92-99

Van de Braak CBT, Taverne N, Botterblom MHA, Van der Knaap WPW, Rombout JHWM (2000) Characterisation of different morphological features of black tiger shrimp (Penaeus monodon) haemocytes using monoclonal antibodies. Fish Shellfish Immunol 10:515-530

Van de Braak CBT, Botterblom MHA, Liu W, Taverne N, Van der Knaap WPW, Rombout JHWM (2002a) The role of the haematopoietic tissue in haemocyte production and maturation in the black tiger shrimp (Penaeus monodon). Fish Shellfish Immunol 12:253-272

Van de Braak CBT, Botterblom MHA, Taverne N, Van Muiswinkel WB, Rombout JHWM, Van der Knaap WPW (2002b) The roles of haemocytes and the lymphoid organ in clearance of injected Vibrio bacteria in Penaeus monodon shrimp. Fish Shellfish Immunol (in press)

Van Hulten MCW, Goldbach RW, Vlak JM (2000) Three functionally diverged major structural proteins of white spot syndrome virus evolved by gene duplication. J Gen Virol 81:2525-2529

Van Hulten MCW, Witteveldt J, Snippe M, Vlak JM (2001a) White spot syndrome virus envelope protein VP28 is involved in the systemic infection of shrimp. Virology 285: 228-233

Van Hulten MCW, Witteveldt J, Peters S, Kloosterboer N and

Editorial responsibility: Timothy Flegel,

Bangkok, Thailand
5 others $(2001 \mathrm{~b})$ The white spot syndrome virus DNA genome sequence. Virology 286:7-22

Van Hulten MCW, Reijns M, Vermeesch AMG, Zandbergen F, Vlak JM (2002) Identification of VP19 and VP15 and glycosylation status of the white spot syndrome virus major structural proteins. J Gen Virol 83:257-265

Wang C, Hassan MD, Shariff M, Zamri SM, Chen X (1999) Histopathology and cytopathology of white spot syndrome virus (WSSV) in cultured Penaeus monodon from peninsular Malaysia with emphasis on pathogenesis and the mechanism of white spot formation. Dis Aquat Org 39:1-11

Wang CH, Yang HN, Tang CY, Lu CH, Kou GH, Lo CF (2000) Ultrastructure of white spot syndrome virus development in primary lymphoid organ cell cultures. Dis Aquat Org 41:91-104

Wongteerasupaya C, Vickers JE, Sriuraitana S, Nash GL and 6 others (1995) A non-occluded, systemic baculovirus that occurs in cells of ectodermal and mesodermal origin and causes high mortality in the black tiger prawn Penaeus monodon. Dis Aquat Org 21:69-77

Wongteerasupaya C, Wongwisansri S, Boonsaeng V, Panyim S, Pratanpipat P, Nash GL, Withyachumnarnkul B, Flegel TW (1996) DNA fragment of Penaeus monodon baculovirus PmNOBII gives positive in situ hybridisation with viral infections in six penaeid shrimp. Aquaculture 143:23-32

Zhan WB, Wang YH, Fryer JL, Okubo K, Fukuda H, Yu KK, Meng QX (1999) Production of monoclonal antibodies (mAbs) against white spot syndrome virus (WSSV). J Aquat Animal Health 11:17-22

Submitted: March 7, 2002; Accepted: April 1, 2002

Proofs received from author(s): August 9, 2002 